6-2015

\title{
Book Review: Violence: The Enduring Problem
}

Christian Gudehus

Ruhr-Universitat Bochum

Follow this and additional works at: https://digitalcommons.usf.edu/gsp

\section{Recommended Citation}

Gudehus, Christian (2015) "Book Review: Violence: The Enduring Problem," Genocide Studies and Prevention: An International Journal: Vol. 9: Iss. 1: 116-118.

DOI:

http://dx.doi.org/10.5038/1911-9933.9.1.1341

Available at: https://digitalcommons.usf.edu/gsp/vol9/iss1/12

This Book Review is brought to you for free and open access by the Open Access Journals at Digital Commons @ University of South Florida. It has been accepted for inclusion in Genocide Studies and Prevention: An International Journal by an authorized editor of Digital Commons @ University of South Florida. For more information, please contact digitalcommons@usf.edu. 
Book Review: Violence: The Enduring Problem

\author{
Christian Gudehus
}

Ruhr Universität Bochum

Violence: The Enduring Problem

Alex Alvarez and Ronet Bachman

Thousand Oaks: Sage, 2014, 350pp. US\$74,00

Reviewed by Christian Gudehus

Ruhr Universität Bochum

\title{
Concept
}

Considering that violence is a prevalent phenomenon and omnipresent in the media, the glaring lack of academic teaching addressing it is astonishing. Accordingly, there are presumably far more courses on peace and conflict studies or genocide studies offered than courses dealing integratively with the various types of violence. Integratively means to approach violence from a broad range of vantage points: to take into account domestic violence as well as genocide and to do so with reference to the insights of the respective relevant disciplines. It is exactly this transdisciplinary approach that is chosen by Alex Alvarez and Ronet Bachman: "All violence is connected by a web of actions and behaviors, ideas, perceptions, and justifications. While the individual dynamics of specific violent behavior may vary somewhat, violent acts share a number of essential characteristics that bind them together into what is sometimes called the unity of human aggression." (p. 3) Their textbook, its language and structure, is obviously aimed at undergraduates and interested laymen. In simple terms they explain comparatively complex phenomena and in doing so they confront what they consider to be widely held misconceptions as, for example, the notion that the larger number of perpetrators suffers from a form of psychological impairment. Observations such as these as well as the overall design illustrate that advanced students, let alone researchers on violence are not the main target group. The same impression may be derived from the cover that is virtually dripping with blood and from the marketing blurb that is used to praise the revised new edition of the book on the back cover. Likewise and typical for a textbook, questions and lists of key terms are provided at the end of each section or else a list of works omitted. All these features as well as the given examples and statistics (for instance on acts of crime), moreover, show that this book was intended for the US audience.

\section{Structure \& Topics}

The strong reference to the US also becomes apparent in the introduction with the heading "As American as Apple Pie." Against the backdrop of the role violence plays in the US society, it discusses definitional questions such as what violence is and, in a next step, how it can be measured. The following chapters introduce various explanatory models derived from diverse academic discourses. Chemical processes are as much taken into account as are psychological explanations and a whole range of sociological approaches. For instance, brain injuries are discussed, the role of the media, the accessibility of weapons as well as the influence of alcohol and other drugs. Subsequently, Alvarez and Bachman tackle various types or else contexts of violence. These comprise assault and murder, violence in the home, robbery, workplace violence, rape, mob violence, terrorism and, finally, genocide. The book concludes with suggestions on how violence may be prevented rendered from the vantage point of public health with a focus on teenagers in the US.

\section{Key Theses}

The book is primarily interesting because despite its textbook structure it espouses some central theses that are taken up repeatedly across all chapters. Most prominently, it claims that violence, 
no matter what its form, is always the result of a specific combination of causes originating from a social, psychological and situational nature. This entails the recognition that the violence actually executed is the result of processes that, at their beginning, are quite undetermined. Accordingly, it can be understood to be the consequence of dynamic processes and conditions that may well have had a different outcome. Due to this, frequently discussed causes and factors are analyzed for their potential to fuel violence or to de-escalate. At this point, further basic factors come into play: that of status and dominance (p. 29). The fight for social recognition is identified as an essential urge triggering acts of violence-or acts of all kinds really-and is spelled out in the various contexts of violence. This applies, for example, to murders. According to Alvarez and Bachman, these can often be attributed to the fact that someone does not feel sufficiently respected or is offended ( $\mathrm{p}$. 30). This aspect continuously recurs in diverse statements, for example, when it is stated that an act of violence is intended to save one's face (p. 66) or to undo the subjective notion that an injustice was committed (p. 89). Thus, emotions come into play that-as must be critically remarked-are not systematically discussed. Likewise, modes of perception, interpretations of the social world and their social framing should be discussed thoroughly since exactly this-how individuals would like to be perceived, how they actually are perceived or believe to be perceived and how the respective perspectives come into existence-according to the authors - is the key to every analysis of violence. Nonetheless, as a matter of fact, a number of socio-theoretical concepts can be found in the book. To give an example, Alvarez and Bachman discuss "script theory" in the context of media audience research. According to this, media - such as films or video games - are not actual causes for violence. Instead, the theory suggests that they influence the way people interpret and perceive situations (p. 44). Exactly with this argument another important point is made: People are shaped by their experiences. Depending on the degree, intensity and, most prominently, positive connotations of violence as part of a person's experience, the likelihood increases that new acts of violence ensue. These excursions into theory are rather short and always reduced in their complexity, which is probably due to the assumed audience. Hence, concepts such as perception and interpretation are employed, yet not investigated in their complexity. However, these easy to stomach references to social theories could be a promising strategy for their successful distribution. After all, for instance the sociology of knowledge, figurational sociological considerations à la Norbert Elias or symbolic interactionism are used as explanatory references.

These references, however, distinguish the intentionality and acts of violence: As it is emphasized that violence is dynamic and a process, a specific viewpoint on the investigated phenomena can be developed. Considering the example of murders, the authors argue, for instance, that these frequently are the result of a "continuum of violence" (p. 79) and hardly ever a predetermined aim. In addition, "this means that, like all social events, the outcome of the encounter depends on the perception and behaviors of the actors involved" (p. 86). Accordingly, acts of violence are not investigated as deeds done by evil people, but as social occurrences that follow the same rules and the same patterns as other, non-violent encounters. This also holds true for terrorist-often labelled as "evil" in the public US discourse - that is scrutinized by taking into account individual behavior. Developments are recapitulated and trivial social aspects of daily life such as questions of belonging, acceptance, prestige and the constructions of meaning, friendship, power and action ability are once more mentioned as relevant factors (p. 238).

As the book is sensationally advertised, its content speaks a different, a de-dramatizing and objectifying language. When the authors indulge in their passion for statistics, perhaps one or the other reader might be inclined to skip over these passages. Yet, this would be a mistake since the detailed investigation of how, for instance, data on "Homicide by Weapon Type" or "Rates of Nonfatal Workplace Violence per 1.000 Employed Persons Age 16 or Older" are accumulated and used, is extremely instructive. This is due to the fact that it sensitizes readers to deal with such information - for instance on youth violence-critically as well as cautiously.

\section{Genocide and Prevention}

So, what does the book contribute to the central topics of the journal and, consequently, to the fields of work of its readership-Genocide and Prevention? Researchers on genocide probably will not learn as much although they might be impressed by the authors' ability to safely lead their readers 
through the variety of explanatory models so that these are comparatively easy to understand. For newcomers, however, the chapter provides a good and comparatively broad introduction to the topic. At the outset, Alvarez and Bachman review definitional problems and introduce cases that are commonly discussed as instances of genocides. In the following, different factors responsible for these mass crimes are shortly discussed and eventually perpetrator types and then victims and bystanders are outlined. After some consideration on international law and genocide the chapter finishes with an assessment rendered in the form of the hope that the new definition of international relations and law in the future "will help prevent" (p. 271) genocides. Actors such as the Islamic State, which is pillaging Iraq and Syria, up until now have remained unimpressed by the statement so that it may be assumed that this hope will remain unfulfilled.

From the point of view of genocide research, the section on prevention is, for the most part, irrelevant because it focuses primarily on crime in the US or else on youth violence. To name but one example: Organized school activities are mentioned as a means to reduce youth violence. That makes sense, but, in the context of genocidal violence, it is probably only efficient to a certain extent.

\section{Problems}

In spite of all these positive aspects, some critical remarks must be made. First of all, violence is (almost) always conceived of as deviant and problematic - as is proved by the subtitle "The enduring Problem." Analyses of desirable or even required violence as it is practiced, for instance, by soldiers, the police and in large-scale livestock farming, are missing. As a consequence, the questions as to why violence as an option to act actually exists and why it does indeed not belong to everybody's repertoire of social actions are not answered. Alvarez and Bachman assume that all humans have a disposition to use violence. Consequently, inhibiting and uninhibiting factors come into play. The fact that a large number of people do not resort to violence-eaving aside symbolic and structural violence-is not discussed.

The apparent intention to include as many different aspects as possible unfortunately entails certain weaknesses. Robbery and bank robbery, for example, are of course related to violence. However, no analysis of violence can be found in the discussion of these cases. It seems that they are only included in the book because they are spectacular. The authors actually do not know what to write about them and how to incorporate them. Also, as has been mentioned, principally the reference to socio-theoretical concepts is a bonus even if the abbreviated versions are partly distorted. Simultaneously, Alvarez and Bachman introduce a comparatively old body of theories. Especially developments in the theory of action as well as practice theory, theories that are relevant for the explanation of all kinds of actions, are not accounted for.

Nonetheless, those who teach in the field of violence studies, especially at introductory levels in educational systems, or who as a layman is interested in the topic and lives in the US, will find the book very rewarding. 